\title{
Mammals of the Transition Zone
}

\author{
FRANK BRAZIER, Regina \\ Pres. Regina Natural History Society
}

It is the intention of the Mammals Team of the Regina Natural History Society to study the mammal life of the Regina Plains within a radius of 50 miles of Regina City. As it is our intention to compare the mammals resident in that area with a checklist of some authority it will be first necessary to construct such a checklist because there seems to be very little material in the literature dealing precisely with this area. About the closest reference is the general term "Southern Saskatchewan" or "The Great Plains" although Anderson in his "Catalogue of Canadian Recent Mammals" makes several useful references to the Transition Zone.

The Zone itself may be defined broadly if inexactly as the Prairie Region south of the Canadian Zone or Forest Belt. However, within the Prairie Region are islands of other Zones, notably the Canadian Zone of Cypress Hills and Moose Mountain, and the semi-arid plains of Southwestern Saskatchewan which is probably Austral Zone or semi-desert. There are recorded as living wilhin this Zone the following mammals, and it will be our task to determine to the best of our ability during next year which of those are resident of the Regina Plains. It will entail considerable field-work as the information concerning the smaller forms of mammal life is somewhat scanty at the best.

There is recorded 1 Canadian Marsupial but none for the Zone; of the 50 forms of Insectivora in Canada we may expect to find 4, all Shrews but no Moles. We may expect 7 of the 29 Canadian Bats with 1 on the Hypothetical List - the Yellowstone Brown Bat which has been taken as far north as Glasgow, Montana. All 4 of the Canadian Primates are resident of the Zone, Homo sapiens (Caucasian), Homo Sapiens afer (Negro), Homo sapiens americanus (Red Indian) and Homo sapiens asiaticus (Monogolian), as well as intergrades within these races but for obvious reasons neither skulls nor skins will be collected.

Only 13 of the 155 Carnivora of Canada are recorded - 1 Raccoon out of 4, none of the 43 Bears although the Big Plains Grizzly was in residence before extinction; of the 15 Canadian foxes only 1 , the Northern Plains Red Fox, may be expected as we have lost our little Kit Fox. From all accounts the Kit appears to have been an amiable little fellow mainly preoccupied with rodent control but whenever opportunity offered he, like any predator, would take poultry. Also, his pelt might fetch upwards of 50 cents. He quickly succumbed to poison and traps and is seen no more in Saskatchewan. Of 23 Wolves 1 form of Coyote may be expected; the Canadian Zone of the Province harbours 2 Timber Wolves, the Saskatchewan race and the Northern, together with their intergrades but only stragglers may be expected in this area. The great Buffalo Wolf is extinct although its blood lines may live on in some of the Wolf races. As far as I can determine, there does not appear to be a single authenticated instance of North American Timber Wolves attacking man unless cornered or fighting for its life; this in contrast to the well documented instances of European Wolves preying on man as casually as on sheep. Otherwise, there appears to be little difference between the species.

Of the 60 Mustelids, neither Marten nor Fisher will be encountered, both inhabiting the deep woods of the Canadian Zone, but 4 Weasels are recorded including the rare Blackfooted Ferret. which is possibly extinct in Saskatchewan; there will be 1 Mink, 1 Skunk and 1 Badger but neither Wolverines nor Otters - on the Hypothetical List for Southern Saskatchewan is the Mackenzie Otter or its intergrade with the Nebraska Otter.

We cannot expect any of the marine forms, of course, neither Sea Otters, nor Finfoots nor Cetaceans. 
The Ogopogo has yet to be officially included in the Canadian Check-list. None of the 10 forms of Cats will be found unless a wandering Bobcat or Cougar should penetrate our defences. The next group are Rodents, of which 212 forms are recorded for Canada. 71 Marmots and Squirrels are listed of which 3 Ground Squirrels will certainly be found but the Black-tailed Prairie Dog is confined to the vicinity of Val Marie in the Saskatchewan Austral Zone. However, it is possible that the Canada Woodchuk will appear as it has been noted here on occasion. The one Chipmunk we will find will be the Northern Interior form but a series taken at Indian Head appeared to be intermediate between the Northern Interior form and the Plains Chipmunk. It is not likely that Flying Squirrels will be found so far from heavy forest cover, nor will we expect other arboreal squirrels.

Only Richardson's Pocket Gopher of the 10 Canadian Gophers is recorded for Southern Saskatchewan and it may be encountered in our area. We can expect Maximilian's Pocket Mouse, the only 1 of the 4 Canadian forms. The Montana Kangaroo Rat has been taken occasionally in Western Saskatchewan but it can hardly be expected in the Regina Plains. The Kangaroo Rat is reported to be the staple food of the Kit Fox in the United States - if the Rat extends its range will the Kit Fox follow?

The next group are the Beavers, 10 in Canada, 1 in our area, then come the Mice and Voles and confusion. 116 forms are recorded.

Perhaps the Grasshopper Mouse is the most interesting of the entire group. While he shares with the 13 striped Ground Squirrel a diet which is $50 \%$ animal matter, a heavy proportion for rodents, it appears to be the only rodent which takes such a high proportion of flesh as opposed to insects. While the Ground Squirrel is reported to kill and eat chancemet mice, the Grasshopper Mouse seems to make a practice of trailing down other mice or pouncing on them from ambush. As it seems to take little grain in its diet, perhaps this is one mouse we should encourage. In addition to this mouse,
Osgoode's White-footed Mouse will probably be met, but the Badlands White-footed Mouse and the Prairie Harvest Mouse may both remain on the Hypothetical List. Both the latter have been collected in North Dakota and may be in residence here.

There seems to be some confusion amongst the Voles - while the genus Clethreonomys should be represented on the Prairie by the Plains Redbacked Mouse, I find that one authority has decided that Drummond's Meadow Mouse, genus Microtus, is the typical Vole of the Central Plains but another authority states the typical Vole of this area should be the Prairie Vole; the latter is specified as Microtus ochrogaster but evidently it has been transferred to the genus Pedomys and is known as Pedomys ochrogaster or Hayden's Meadow Mouse. The Badlands Meadow Mouse should also be met in Saskatchewan as well as intergrades with it and Drummond's but I cannot tell which to expect on the Regina Plains. The Little Upland Mouse and the Pallid Pigmy Vole may both be in residence in Saskatchewan but what voles and mice live in the Regina Plains can be determined only by an extensive trapping programme.

These Voles are those which can spell economic disaster for us if not closely controlled. Not only are they prolific but they harbour diseases that can spread to man and his livestock. Every predator of the plains and all predators and some rodents which include mice in their diets, should be encouraged to remain. True, such predators as we have will also take poultry if poultry are permitted to run at large or if carelessly housed but those losses will be small indeed to the losses we will suffer if the Microtus group particularly get out of hand.

One form of Muskrat is found and it is interesting to note that the introduced Nutria appears to have solved Michigan winters and is establishing itself in a small way in the Central States.

The Old World Rats and Mice are represented here by 2 forms, the Brown Rat and the House Mouse. There is no doubt that rats are one of our most important mammals I suppose more history has been 
moulded by the defeats of man through the diseases spread by rats than the victorious armies of kings. The rat has killed scores of millions of humans. We should mobilize all our resources to exterminate it once and for all.

The Rodents are completed in Saskatchewan by two forms of Jumping Mice if the Prairie Jumping Mouse resides here, otherwise only the Saskatchewan form may be found and finally the Nebraska Yellowhaired Porcupine.

The Lagomorphs are represented in Canada by 31 forms but only 3 may be met in Saskatchewan - the White-tailed Jack Rabbit, American Varying Hare and Black Hills Cottontail. The Nebraska Cottontail is on the Hypothetical List and may have reached our area. The Lagomorphs have recently been separated from the Rodents with which they were long included on the basis of certain anatomical differences, some of which are obvious to the layman, such as the development of the legs which indeed gave rise to the term "lagomorph"; the teeth are different as well, pikas, hares and rabbits have four incisors in the upper jaw whereas rodents have two, and the incisors of lagomorphs have protecting enamel over much of the inside sur- faces as well as over all the front surface while rodents have enamel on the front of the incisors only.

The final group is the Even-toed Ungulates or Hoofed Mammals of which there are 36 forms in Canada: 23 deer, 1 Pronghorn and 12 Bovidae, that is, Bison, Muskoxen, Sheep and Goats. The Manitoba Elk may be here (definitely in the Canadian Zone of Moose Mountain), certainly the Northern Plains White-tailed Deer but Mule Deer may not range on to the Regina Plains. While Moose Jaw has a legend concerning the origin of its name, and while the odd relics of Moose are picked up occasionally on the Plains, it does not seem likely that Moose considered the Transition Zone its normal habitat in historical times if the type of country it inhabits today is any indicationit has always been associated with Canadian Zone throughout North America; similarly with the European form, known there as Elk. The Plains Bison is extinct in the wild state, while the modern form of Muskoxen appear to be confined to the Hudsonian Zone or tundra. Mountain Sheep and Mountain Goats complete the Canadian Check-listwe have neither mountains, nor sheep, nor goats.

Frank Brazier

\section{FRANK BAINES HEADS SALTCOATS CONSERVATION SOCIETY}

An organization meeting of the Saltcoats and district Conservation Society was held in the Saltcoats Fire Hall on Friday evening, August 20th. Officers elected were: President, Frank Baines; Vice-President, George Wiley; Secretary, Miss Patsy Hodgins; Executive, Jim Murray and L. R. Lordly. Membership fees were set at $50 \mathrm{c}$ for adults, $25 \mathrm{c}$ for high school students and $10 \mathrm{c}$ for public school students.

The meeting voted to affiliate with the Saskatchewan Natural History Society and adopt the "BLUE JAY" as the official bulletin of the new Society. Several projects were discussed. A delegation will attend the annual meeting of the Saskatchewan Natural History Society in Yorkton on Saturday, October 23rd. The first public meeting at Saltcoats will be held after harvest.

\section{INTERESTING BIRDS}

(Continued from Page 26)

Woodpecker appeared around the nearest tree trunk. On the other side, where a clump of Saskatoon and Raspberry bushes grew, a Robin and two Waxwings were eating the berries. Later when picking Saskatoons, I noticed little three-cornered nips in the berries. Do the saucy fellows taste them before eating them? When startled they all fly up into the tall pine trees, and you wouldn't know there were any birds around.

Squirrels are plentiful here too. One amused us by scampering across the clearing with a whole slice of toast in his mouth. I could just hear him call "Breakfast is ready children". 